\title{
Turbidity and oil removal from oilfield produced water, middle oil company by electrocoagulation technique
}

\author{
Thamer Mohammed ${ }^{1}$, Esraa Abbas $^{1}$ and Thabit Ahmed ${ }^{1}$ \\ ${ }^{1}$ Chemical Engineering Department, University of Technology, Baghdad, Iraq
}

\begin{abstract}
Huge quantity of produced water is salty water trapped in the oil wells rock and brought up along with oil or gas during production. It usually contains hydrocarbons as oil and suspended solids or turbidity. Therefore the aim of this study is to treat produced water before being discharge to surface water or re_injected in oil wells. In this paper experimental results were investigated on treating produced water (which is obtained from Middle Oil Company-Iraq), through electrocoagulation (EC). The performance of EC was investigated for reduction of turbidity and oil content up to allowable limit. Effect of different parameters were studied; $(\mathrm{pH}$, current density, distance between two electrodes, and electrolysis time). The experimental runs carried out by an electrocoagulation unit was assembled and installed in the lab and the reactor_was made of a material Perspex, with a capacity of approximately 2.5 liters and dimensions were $20 \mathrm{~cm}$ in length, $14 \mathrm{~cm}$ in width and $16 \mathrm{~cm}$ height. The electrodes employed were made of commercial materials. The anode was a perforated aluminum rectangular plate with a thickness of $1.72 \mathrm{~mm}$, a height of $60 \mathrm{~mm}$ and length of $140 \mathrm{~mm}$ and the cathode was a mesh iron. The current was used in the unit with different densities to test the turbidity removing efficiency $(0.0025,0.00633,0.01266$ and $0.0253 \mathrm{~A} / \mathrm{cm} 2)$. The experiment showed that the best turbidity removing was $(10,9.7,9.2,18 \mathrm{NTU})$ respectively. The distance between the electrodes of the unit was $3 \mathrm{~cm}$. The present turbidity removing was $92.33 \%$. A slight improvement of turbidity removing was shown when the distance between the electrodes was_changed from 0.5 to $3 \mathrm{~cm}$ with fixation of current density. The best turbidity removing was $93.5 \%$, (7.79 NTU) when the distance between the electrodes were $1 \mathrm{~cm}$. The experimental results found that concentration of oil had decreased to $(10.7,11.2,11.7,12.3) \mathrm{mg} / \mathrm{l}$ when different current densities $(0.00253,0.00633,0.01266,0.0253) \mathrm{A} / \mathrm{cm} 2$ were used, respectively with the distance between the electrodes was $3 \mathrm{~cm}$. The best result of oil content decreasing was $10.7 \mathrm{mg} / 1$ with current density $0.0253 \mathrm{~A} / \mathrm{cm} 2$. These results are within allowable limit to provide the possibility of reuse the water and can be injected in oil wells
\end{abstract}




\section{Introduction}

During the process of producing oil or gas from underground formations, trapped water is brought to surface along with oil or gas. This water is known as produced water in upstream oil and gas operations. On a global spectrum, it is found that 3 barrels of water produced for every barrel of crude oil. The ratio of water to crude oil is about 10:1 in North America, [1]. Lee et al., [2] found that for every 1 billion of oil, $7 \mathrm{bb} 1$ of water is produced. Therefore treatment and disposal of produced water is becoming a leading economic factor in viability assessment of the asset and it discharges within allowable limit of environmental regulations. This major problem in the $21^{\text {st }}$ century effects on quality of water because of increasing pollution from point and non-point sources and become a crucial problem, particularly for the ThirdWorld Countries, [3]. The promising technical methods based on electrochemicals are electrocoagulation, electro flotation [4], electro decantation, and others [4-6].

But in recent years the treatment by electrocoagulation (EC) has been widely used for the treatment of wastewater having oil wastes, turbidity or suspended solids [7-8], organic matter from landfill leachate [9], heavy metals [10], phenolic waste. This technique has multi benefits [5]: such as compatibility, amenability to automation, cost effectiveness energy efficiency, without use coagulants, safety, and versatility. This process has capability to overcome the disadvantages of other treatment methods [1]. The literature surveys indicated that EC has the capability of removing turbidity and most of the water contaminant in oily wastewater and produced water [11-13]. Electrocoagulation (EC) is a complicated process involving many chemical and physical phenomena that use sacrificial electrodes, such as $\mathrm{Al}, \mathrm{Fe}$ and others, to supply ions into the water [14]. In the EC process, the coagulants are generated in situ by dissolving electrically the consumable electrodes ( $\mathrm{Fe} / \mathrm{Al})$. The metal ions generation takes place at the anode; hydrogen gas is released from the cathode [15]. In the solution, the metal cations resulted from the anode oxidation combine with hydroxyl ion $\left(\mathrm{OH}^{-}\right)$resulting from water to form highly charged coagulant. In the case of Aluminum anode, the $\mathrm{Al}^{3+}$ reacts with $\mathrm{H}_{2} \mathrm{O}$ to form $\mathrm{Al}(\mathrm{OH})_{3}$, and in the case of magnesium anode, the $\mathrm{Mg}^{2+}$ reacts with $\mathrm{H}_{2} \mathrm{O}$ to form $\mathrm{Mg}(\mathrm{OH})_{2}$. The basic process can be summarized in Fig. 1. The aim of the present work is to remove suspended solid and oil from produced water which is obtained from Middle Oil
Company by EC and study different parameters effect on removal efficiency.

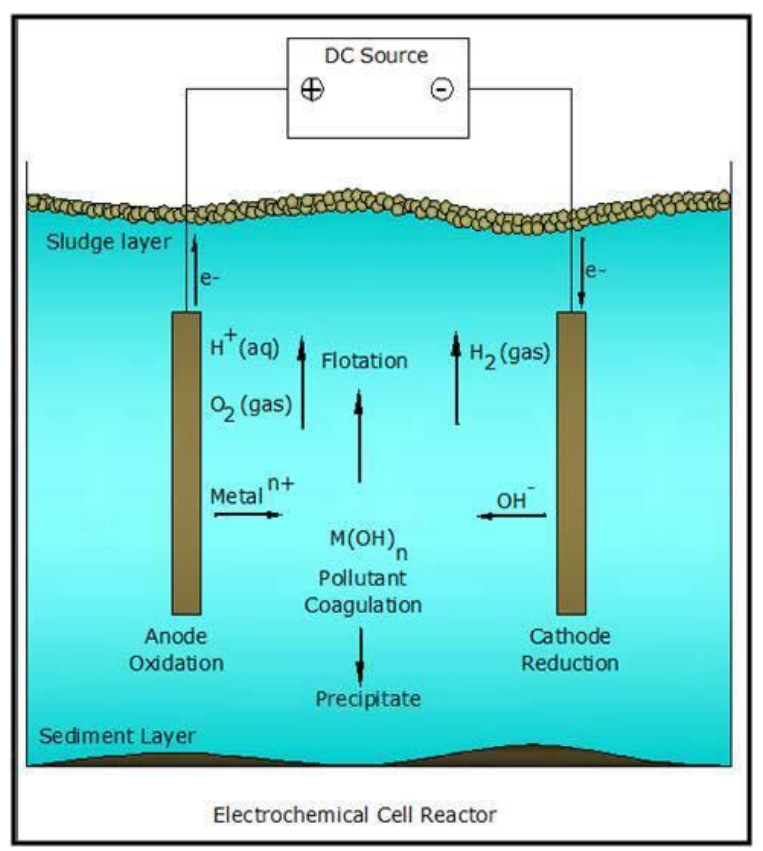

Fig. 1 Interactions occurring within an electrochemical reactor

\section{Experiment}

\subsection{Characteristics of oilfield produced water}

Oilfield produced water used in the present study was kindly provided by Petroleum Research and Development Center staff from Middle Oil Company.

Its chemical and physical characteristics include $\mathrm{pH}$ around (7), EC (144300 $\mu \mathrm{s} / \mathrm{cm})$, Turbidity (120 NTU), oil content $(46.6 \mathrm{mg} / \mathrm{l}), \quad$ TDS $(133477 \mathrm{mg} / \mathrm{l})$ and TSS $(90 \mathrm{mg} / \mathrm{l})$.

\subsection{Materials and methods}

Monopolar aluminum and iron electrodes were used in the electro coagulation cell to form coagulants for the purpose of oil and turbidity removing from produced water. Experimental work was conducted at the laboratories of the Chemical Engineering Department of Technology University in Baghdad. The electrodes used were made with commercial materials. The anode was a perforated aluminum rectangular plate with a thickness of $1.72 \mathrm{~mm}$, a height of $60 \mathrm{~mm}$ and length of $140 \mathrm{~mm}$; these were perforated in order to increase the contact surface area, which increases the electron transfer. The cathode was 
constructed with iron mesh, which provides a large area for the reaction. For the preliminary study of the process variables (applied current, distance between the electrodes and electrolysis time) were taken.- The reactor is made of a material Perspex, with a capacity of approximately 2.5 liters. The dimensions were $20 \mathrm{~cm}$ in length, $14 \mathrm{~cm}$ in width and $16 \mathrm{~cm}$ height shown in Fig. 2. The electrodes used in this cell were variable distance.

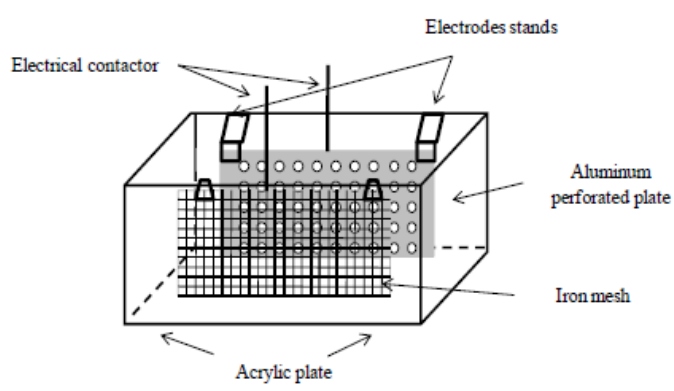

Fig.2 : Electrocoagulation cell

Determination of the effect of current density on the reaction of electro- coagulation was carried out in a parallel-plate cell. In these experiments, $2 \mathrm{~L}$ of the sample produced water were transferred to the electrochemical cell with parallel plates as shown in Fig. 3. Once the water to be treated was transferred, the magnetic stirrer was at slow speeds), the electrodes were connected to the power supply by which the work circuit current (ranged 0.2 A - 0.5 A - 1 A -2 A) was established. The initial turbidity was determined, and the system was then allowed to react, measuring turbidity at different time intervals. For experiments with different currents, the distance between electrodes was kept fixed. Once the experiment was completed, the procedure described above was repeated but with a change in the distance between electrodes ranged $(0.5 \mathrm{~cm}, 1 \mathrm{~cm}, 2 \mathrm{~cm}, 3 \mathrm{~cm})$.

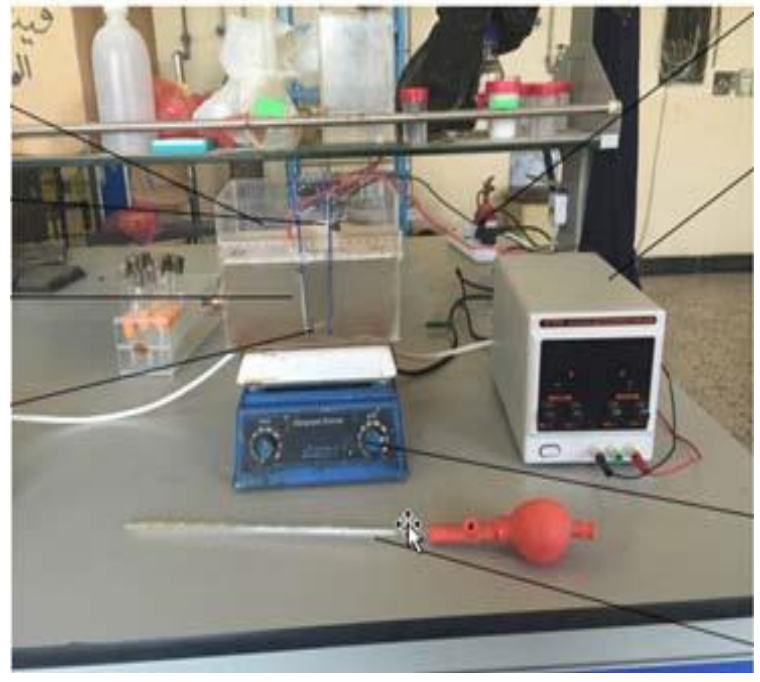

Fig. 3 : photographic picture of EC cell at Chemical. Eng. Labs, Technology Unv, Baghdad.

\section{Results and discussion}

\subsection{Effect of current density on the turbidity}

Four current densities $(\mathbf{I}=\mathbf{0 . 0 0 2 5 3}, \mathbf{0 . 0 0 6 3 3}, \mathbf{0 . 0 1 2 6 6}$, and $\mathbf{0 . 0 2 5 3} \mathbf{A} / \mathbf{c m 2}$ ) were applied to examine the effect of current on the electrocoagulation treatment of produced water. The effect of current density on the turbidity removal efficiencies is depicted in Fig. 4 to 7.The removal efficiency increases with the applied current density. The removal efficiencies of turbidity were 91.6, 91.9, 92.3 and $85 \%$ with residual turbidity $(10,9.7,9.2$, and 18) of current densities, respectively. It has been found that the best value is where the current density $\left(\mathbf{0 . 0 1 2 6 6 ~} \mathrm{A} / \mathrm{cm}^{2}\right)$ which gives the best results for removal efficiency $(92.3 \%)$. The effectiveness of current density on increasing removal efficiency slows down at higher current densities. The rate of anodic dissolution of aluminum is increased at higher current densities, resulting in a greater amount of coagulant and precipitant production. Consequently, this results in a higher removal efficiency of turbidity. Bubble size decreases, while bubble generation rate increases with current density, which results in higher removal efficiency of turbidity via $\mathrm{H} 2$ flotation, in addition to this the effect of coagulation were agreed with this result of [16]. 


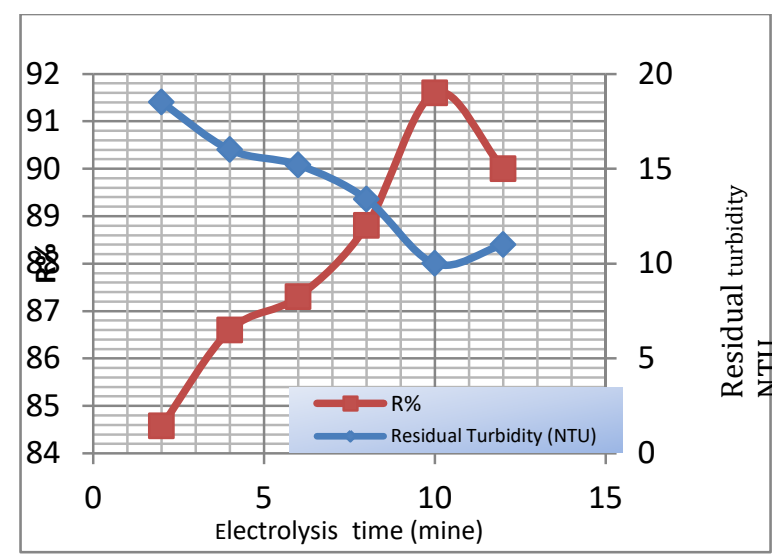

Fig. 4: Effect of the current density $\left(0.00253 \mathrm{~A} / \mathrm{cm}^{2}\right)$ on the turbidity

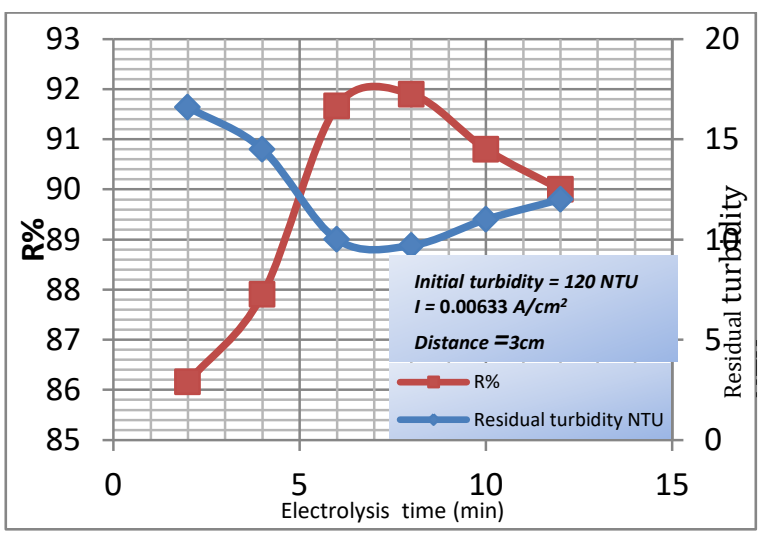

Fig. 5: Effect of the current density $\left(0.00633 \mathrm{~A} / \mathrm{cm}^{2}\right)$ on the turbidity

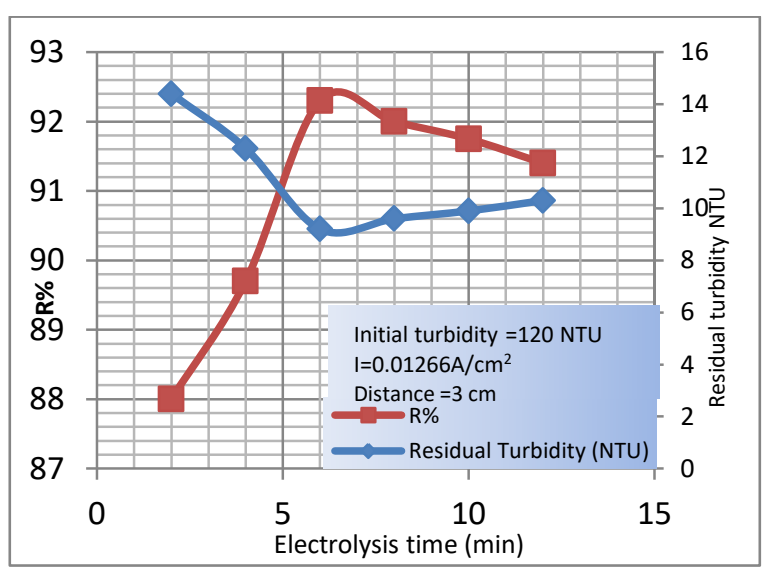

Fig. 6: Effect of the current density $\left(0.01266 \mathrm{~A} / \mathrm{cm}^{2)}\right.$ on the turbidity

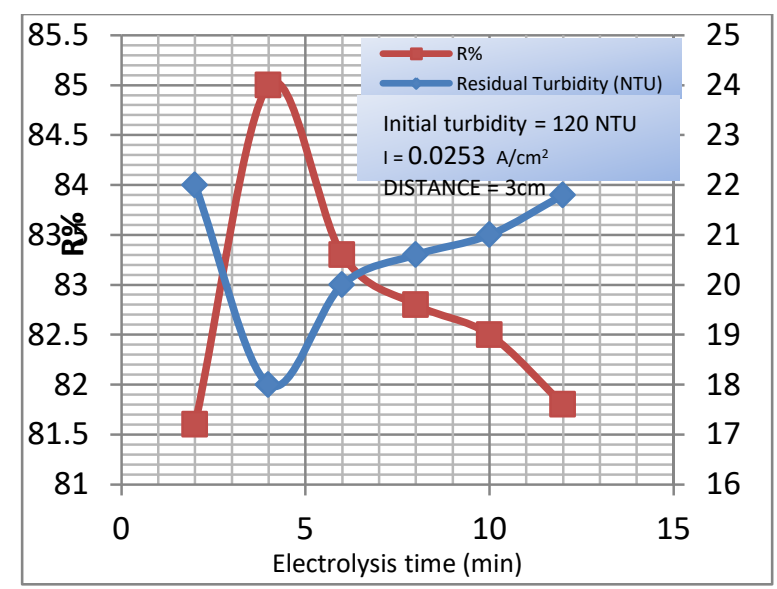

Fig. 7: Effect of the current density $\left(0.0253 \mathrm{~A} / \mathrm{cm}^{2}\right)$ on the turbidity

\subsection{Effect of distance between the electrodes on the turbidity}

Four experiments were performed under fixed operational condition $(\mathrm{pH}=6.98$, current density $\mathbf{I}=\mathbf{( 0 . 0 1 2 6 6}$ $\mathbf{A} / \mathbf{c m} 2$, and electrolysis time (2-12 minutes) and altering distances $(0.5,1,2$ and $3 \mathrm{~cm})$ between electrodes. The results show in Fig. 8 that the turbidity decreased slightly when the distance was increased from $\mathbf{0 . 5}$ to $\mathbf{1} \mathrm{cm}$ (from 7.9 to 7.79) NTU, but the turbidity increased to $9 \mathrm{NTU}$ when the distance between electrodes was kept 2 and 3 $\mathrm{cm}$. Thus, the optimal distance was shown to be approximately $1 \mathrm{~cm}$. This can be explained that decreasing the space between electrodes results in low resistance through the solution which in turn results in increasing the rate of Aluminum dissolution and $\mathrm{Al}^{+3}$ releases and consequently leads to more turbidity removal from the solution. On the other hand, decreasing the space could enhance the flotation process by limiting the generated bubbles in a narrow space which results in higher removal efficiencies. 


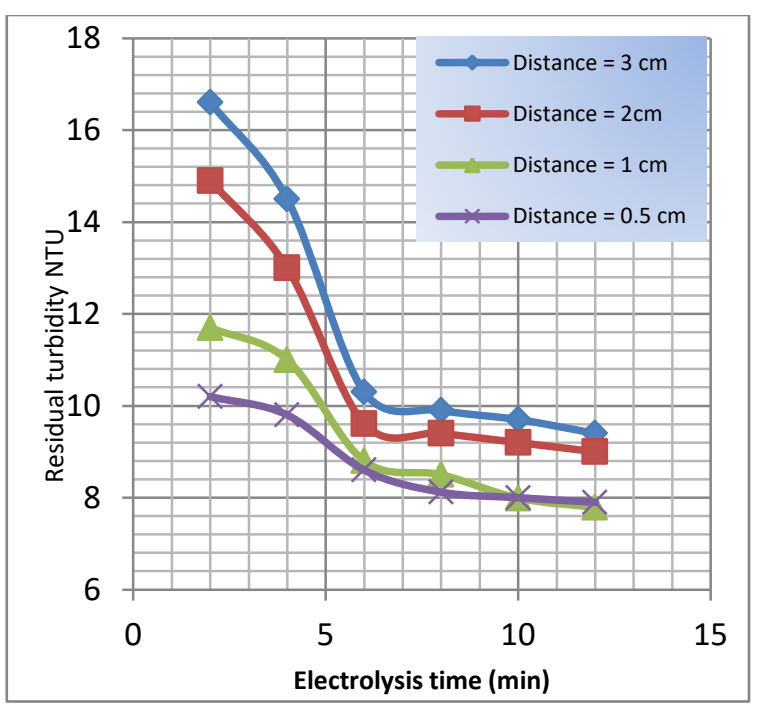

Fig. 8 Effect of distance between electrodes on the turbidity ( t 2-12) minutes, $\mathrm{pH}=6.98, I=(0.01266$ $\mathrm{A} / \mathrm{cm}^{2}$ )

\subsection{Effect of Initial pH}

Aluminum ions may be found in different forms and phases, depending on the $\mathrm{pH}$ and chemical characteristics of the solution. At $\mathrm{pH}$ values less than 4, aluminum ions that are released from electrodes can be found in the form of $\mathbf{A I}\left(\mathrm{H}_{2} \mathrm{O}\right)_{6}{ }^{+3}$, while at a $\mathrm{pH}$ range of 5 to 6 , aluminum $\mathrm{m}$ the $\mathrm{pH}$ rises to higher values (5 to 8 ), aluminum changes to the form $\mathrm{AI}(\mathrm{OH})_{3}$. $\mathrm{pH}$ values greater than 8.8 may cause dissolution of aluminum as ions again. Based on the effect of $\mathrm{pH}$ on the chemical form of aluminum, it is expected that electro coagulation efficiency would be dependent on $\mathrm{pH}$, to some extent. Five experiments at initial $\mathrm{pH}$ values of $5,6,7,8$ and 9 were performed to investigate this effect. The results presented in Fig.9 shows that the optimal residual turbidity is achieved at $\mathrm{pH}$ value of 7 .

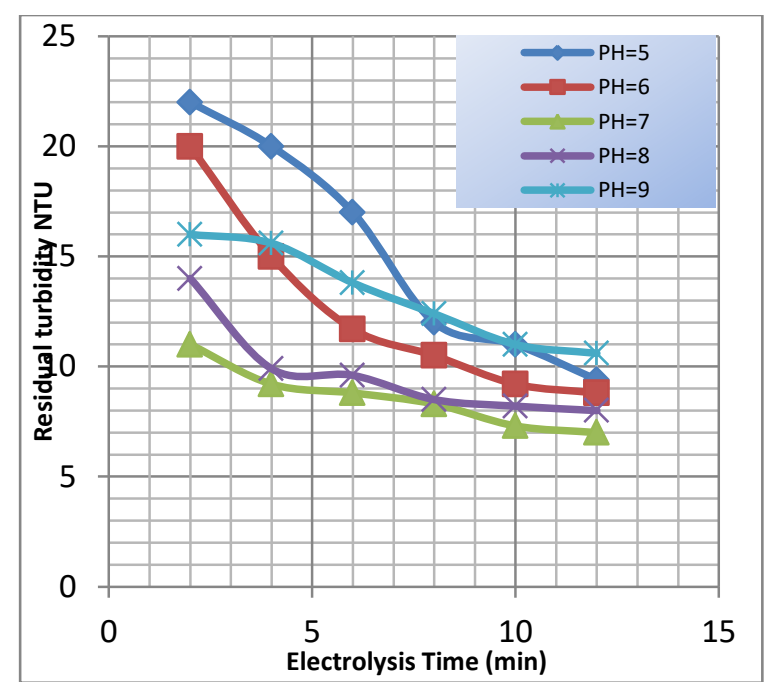

Fig. 9 Effect of initial $\mathrm{pH}$ on the turbidity (t 2-12) minutes distance $=1 \mathrm{~cm}, I=\left(0.01266 \mathrm{~A} / \mathrm{cm}^{2}\right)$. Content Distance $=3 \mathrm{~cm}$ and initial oil content $46.6 \mathrm{mg} / 1$

\subsection{Effect of the current density on the Oil Content Distance $=3 \mathrm{~cm}$ and initial oil content $46.6 \mathrm{mg} / \mathrm{l}$}

The results shown in Fig 10 depict the effect of current density on the oil content removal .It was found that oil content removal increases with increasing current density. It was found that the best removal achieved when the current was $(\mathbf{0 . 0 2 5 3} \mathrm{A} / \mathrm{cm} 2)$ where the oil content reached (10.7 $\mathrm{mg} / \mathrm{l})$ after $10 \mathrm{~min}$. The higher $(\mathbf{0 . 0 2 5 3} \mathrm{A} / \mathrm{cm} 2)$ current density has no significant effect on the removal efficiency of oil. This is ascribed to the fact that at higher current densities, the dissolution of anode electrode increases according to Faraday's law; the resulting metal hydroxides produce more sludge.

\subsection{Effect of distance between the electrodes on the oil content}

Four experiments performed under fixed operational condition $(\mathrm{pH}=6.98$, current density $\mathrm{I}=0.0253$ $\mathrm{A} / \mathrm{cm} 2$, electrolysis time (2-12 minutes) and altering distances $(0.5,1,2$ and $3 \mathrm{~cm})$ between electrodes. The results shown in Fig 11 display that the oil content decreased slightly with the distance from 0.5 to $10.2 \mathrm{mg} / 1$. Thus, the best distance was shown to be approximately $0.5 \mathrm{~cm}$. 


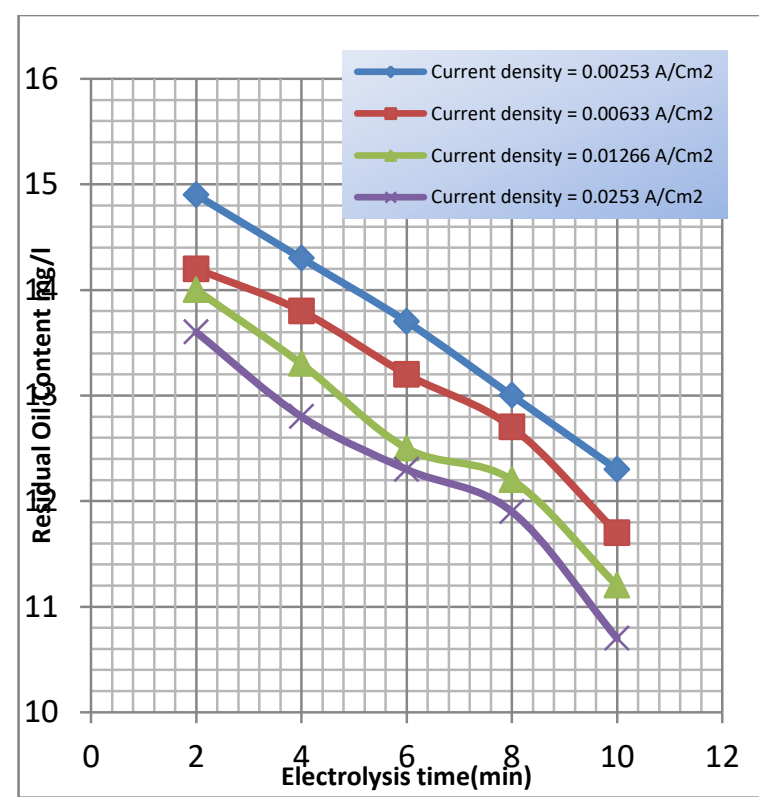

Fig. 10 Effect of current density on the Oil Content Distance $=3 \mathrm{~cm}$ and Initial oil content $=46.6 \mathrm{mg} / \mathrm{l}(\mathrm{pH}=$ $6.98)$

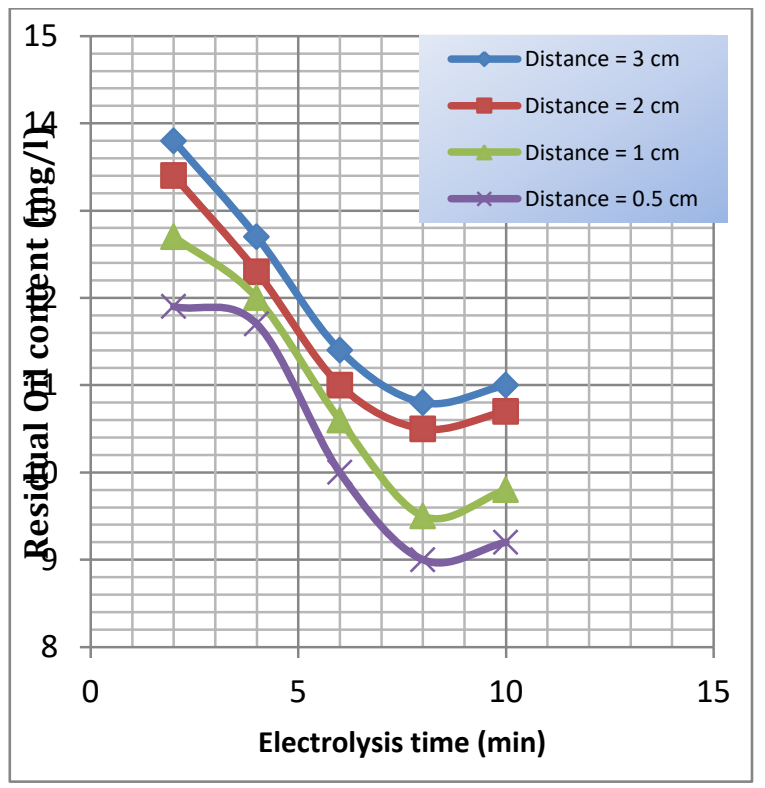

Fig. 11 Effect of distance between the electrodes on the oil content at $(\mathrm{I}=0.0253 \mathrm{~A} / \mathrm{cm} 2)(\mathrm{t}=2-10 \mathrm{~min})$

\section{Comparisons between experimental and theoretical sacrificial Aluminum anode consumption}

A comparison between experimental and theoretical sacrificial aluminum anode consumption has been achieved by calculating the theoretical Al loss from the anode using Faraday's equation and compared with those obtained experimentally [17].

$$
w=\frac{i t M}{N f}, \quad \text { Faraday's law }
$$

$N=3$ is the number of electrons corresponding to aluminum oxidation, $M$ is the molecular weight $(\mathrm{mg} / \mathrm{mol})$ and $f$ is Faraday's constant (96 500 $\mathrm{C} /$ mole), $\mathrm{i}=$ current $(\mathrm{A}), \mathrm{t}=$ time ( $\mathrm{sec}$ ), and the second value is determined from the aluminum anode consumption by weighing the electrode before and after experiment. The results shown in Fig 12 and Table (1.1) describe the amount of $\mathrm{Al}$ generated from anode always exceeded by those calculated theoretically from Faraday's equation. The reason for this may be due to the fact that Faraday's law does not take into account the impact of salt in PW on Metal dissolution while the salt has a strong effect on the rate of dissolution by increasing the conductivity of the solution.

\section{Conclusions}

a. In Electrocoagulation method, by using different current densities $(\mathbf{0 . 0 0 2 5 3}, \mathbf{0 . 0 0 6 3 3}, \mathbf{0 . 0 1 2 6 6}$, and $0.0253 \mathbf{A} / \mathbf{c m} 2)$ it is found that the best current density is $(0.01266 \mathbf{A} / \mathbf{c m} 2)$ to reduce turbidity removal efficiency and residual turbidity up to (92.3\%), (9.2 NTU), respectively at constant distance between electrodes $3 \mathrm{~cm}$.

b. Experiments carried out using different distances between electrodes $(0.5,1,2,3 \mathrm{~cm})$ showed that the best distance to reduce removal turbidity up to (7.79NTU) is $1 \mathrm{~cm}$.

c. The experimental results observed the effect of initial $\mathrm{pH}$ on turbidity removal efficiency with electrocoagulation treatment. The best value is $\mathrm{PH}$ $=7$ to obtain turbidity removal efficiency $(94.1 \%)$.

d. In the electrocoagulation methods, the oil content could be decrease to $(10.8,10.5,9.5,9) \mathrm{mg} / \mathrm{L}$ with different distances between electrodes at constant current $(0.0253 \mathrm{~A} / \mathrm{cm} 2)$. 
Table (1.1):- Experimental and Theoretical Sacrificial Aluminum Anode Consumption

\begin{tabular}{|c|c|c|}
\hline $\begin{array}{c}\text { Current } \\
\text { density } \\
\text { A }\end{array}$ & $\begin{array}{c}\text { Al } \\
\text { consumption } \\
\text { based on } \\
\text { Faraday's } \\
\text { law (gm Al) }\end{array}$ & $\begin{array}{c}\text { Al } \\
\text { consumption } \\
\text { (gm) } \\
\text { experimental }\end{array}$ \\
\hline 0.2 & 0.0111 & 0.01566 \\
\hline 0.5 & 0.0279 & 0.039 \\
\hline 1 & 0.0559 & 0.071 \\
\hline 2 & 0.1119 & 0.17948 \\
\hline
\end{tabular}

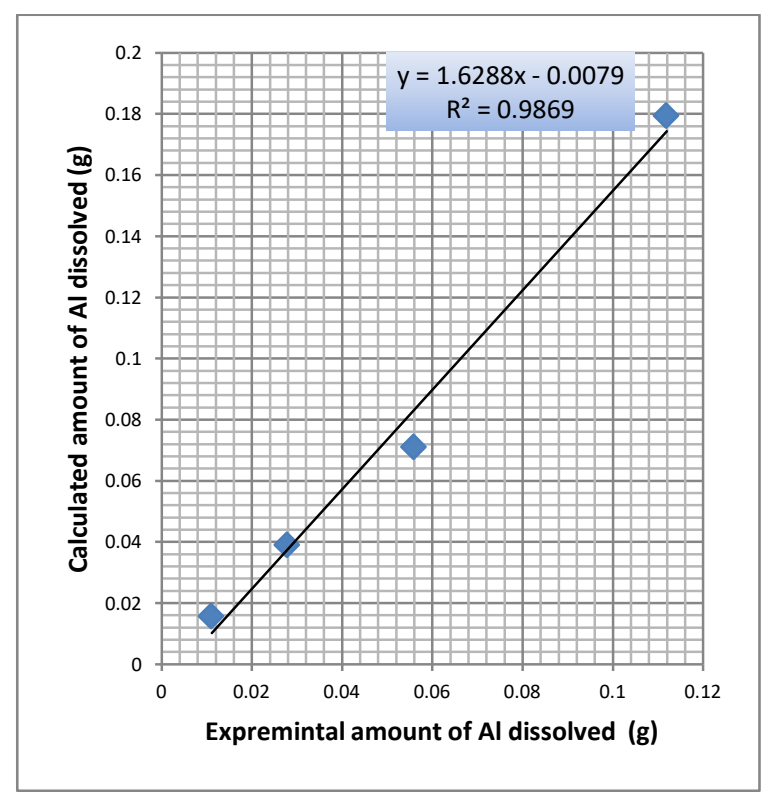

Fig. 12 : Measured Vs. calculated amount of Al released from the anode

\section{References}

1. BakerCorp "Treatment Of Produced Water By Electrocoagulation" water treatment solution.(2014).

2. Lee, R., Seright, R., Hightower, M., Sattler, A., Cather, M., Mcpherson, B., Wrotenbery, L., Martin, D., and Whiteworth, M., "Strateries for Produced Water Handling in New Mexico" Conference, Colorado Springs, Co. 16-17, Oct. (2000).

3. Satish, I., Chaturredi, "Electrocoagulation; A Novel Wastewater Treatment Method" I. JMER, Vol.3, Issue, 1, Jan-Feb. PP. 93-100, (2013).
4. Rajeshwar, K., Ibanez, J.G. and Swain, G.M., " Electrochemistry and the environment",J. APL. Electrochem., 24, 1077, (1994).

5. Mollah,M.Y.A., Schennach, R., Parga, J.R. and Cocke, D.L, " Electrocoagulation (EC)--science and applications.," J. Hazzard Matter, 84, 29-41, (2001).

6. M. Y. A. Mollah, P. Morkovsky, J. A. G. Gomes, M. Kesmez, J. Parga, and D. L. Cocke, "Fundamentals, present and future perspectives of electrocoagulation," Journal of Hazardous Materials, vol. 114, no. 1-3, pp. 199-210, (2004).

7. Donini, J.C.; Kan, J.; Szynkarczuk, J.; Hassan, T.A.; Kar, K.L. Operating cost of electrocoagulation. Can. J. Chem. Eng., 72 (6): 1007.. (1994).

8. Abuzaid, N.S., Bukhari, A.A., Al Ha mo uz, Z.M., ". Removal of bentonite causing turbidity by electrocoagula-tion". J. Environ. Sci. Health, Part A A33, 1341-1358, (1998).

9. CT Tsai, ST Lin, YC Shue, PL Su "Electrolysis of soluble organic matter in leachate from landfills" Water Res., 31, 3073, (1997).

10.V.L. Pogrebnaya, A.A. Klimenko, T.N. Bokovikova, E.P. Tsymbal, N.P. Pronina, "Purification of waste water of heavy metals by electrocoagulation", Chem. Petrol. Eng. 31 , 280, (1995).

11. Maria Elektorowicz, Shiva Habibi, Rozalia Chifrina , " Effect of electrical potential on the electrodemulsification of oily sludge" Journal of Colloid and Interface Science 295 535-541, (20006).

12. McBeth, I., Reddy, K.J., Skinner, Q.D. "Chemistry of Trace Elements in Coalbed Methane Produced Water" Water Research, 27,884-890, (2003).

13. Tir, M., Moulal-Mostefa, N., "Optimization of Oil Removal from Oily Wastewater by EC Using RSM" J. of Hazards Material, 158, 107-115, (2008).

14. Liu, H., Zhao, X., and Qu, J., "Electrocoagulation in Water Treatment." From: Electrochemistry for the Environment, Chapter 10. Comninellis, C and Chen, G. (eds.), Springer.(2010).

15. Lawrence K., Yung Tse, Nazih K.,,"Advanced Physicochemical Treatment Technologies", Humana Press, Totowa, New Jersey, p 64-65. (2007).

16. Song, S.; Yao, J.; He, Z.; Qiu, J.; Chen, J. Effect of Operational Parameters on the Decolorization of C.I. Reactive Blue 19 in Aqueous Solution by Ozone-Enhanced Electrocoagulation. J. Hazard. Mater. 152, 204-210. (2008).

17. 8- Christos C. and G. Chen,, "Electrochemistry for the Environment, Springer", New York, pp. 245-262., (2010). 